\title{
Ecological Aspect of the Usage of Ahy and Slag Waste in the Chechen Republic
}

\author{
Murtazaev S-A.Y. \\ Department of materials science and engineering \\ Kh. Ibragimov Complex Institute of the Russian Academy \\ of Sciences \\ Technical sciences department \\ The academy of science of the Chechen Republic \\ Grozny State Petroleum Technical University \\ named M.D. Millionschikov \\ Grozny, Russia \\ s.murtazaev@mail.ru

\section{Mintsaev M.Sh \\ Building faculty} \\ Grozny State Petroleum Technical University named M.D.

$$
\text { Grozny, Russia }
$$$$
\text { Millionschikov }
$$$$
\text { ranas@rambler.ru }
$$

\author{
Salamanova M.Sh. \\ Department of materials science and engineering \\ Kh. Ibragimov Complex Institute of the Russian Academy \\ of Sciences \\ Building faculty \\ Grozny State Petroleum Technical University named after \\ M.D. Millionschikov \\ Grozny, Russia \\ e-mail:madina salamanova@mail.ru
}

\author{
Saydumov M.S. \\ Building faculty \\ Grozny State Petroleum Technical University named after \\ M.D. Millionschikov \\ Grozny, Russia \\ saidumov_m@mail.ru
}

\author{
Aliev S.A. \\ Building faculty \\ Grozny State Petroleum Technical University named after M.D. Millionschikov \\ Grozny, Russia \\ asa-fenix@mail.ru
}

\begin{abstract}
Nowadays the development of new efficient composites based on secondary resources for high-rise construction is a relevant issue. The basis of the production of high-strength concrete is based on modern technological methods that improve technical, physic and mechanical properties, with the integrated application of industrial raw materials and effective chemical additives. The article presents the compositions and studies the properties of high-strength concretes on enriched aggregates and mixed binders with fine ash filler.
\end{abstract}

Keywords-industrial raw material, ashy binder, bottom-ash compounds, wastes of the fragmentation of the rock, superplasticizer, ashy microspheres, high-strength concrete, crusher-run aggregate

\section{INTRODUCTION}

The global increasing industrial production entails the accumulation of huge volumes of industrial or man-made waste, the elimination and storage of which present economically and ecologically difficult task. Therefore, the resource-saving technologies for the production of modern building composites are of particular interest and industrial waste is becoming a valuable and scarce raw material of considerable practical interest in the production of building materials, allowing to satisfy raw material requirements up to $40 \%[1,2,6,7]$.

The scientific and theoretical studies conducted in this field $[3-5,8,9]$ prove that the use of sludge, slag, ashy waste and waste of mining and processing plants, oil refining, etc. provides an opportunity to receive not only traditional, but also new, more effective building materials with a wide range of improved technical characteristics.

A particularly large amount of secondary industrial wastes in the form of ashes and slag, as well as their compounds, is formed when solid fuels are combusted. Depending on the origin of fuel, the amount of generated waste is: in coal - up to $40 \%$, in brown coal - up to $15 \%$, in anthracite and fuel peat - up to $30 \%$, in combustible shale - up to $60 \%[1,2,10]$. The usage of ashy and slag raw materials in the production of building materials has a very wide range: road construction, production of composite binders, micro fillers, various types of concrete, aggregates, etc.

Since the 30 s of the last century and until the beginning of the crisis events in the Chechen Republic taking place at the turn of the century, there was a lot of Heating Power Plants (HPP) operating in the Republic. For many years of operation of HPPs thousands of tons of ash and slag wastes were accumulated, occupying vast territories of hundreds of hectares and polluting the environment (Figure 1). In this regard, the complex development with the production of concrete composites is not only relevant, but also very effective. 

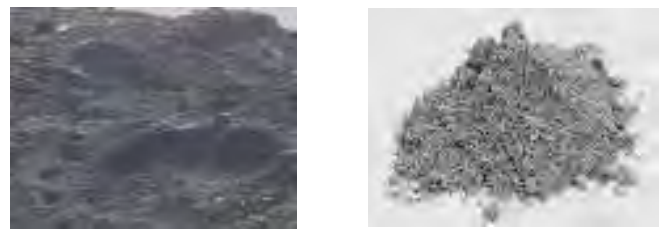

Fig. 1. Bottom-ash waste in Grozny.

\section{METHODS AND MATERIALS}

However this research presents the results of the study of the properties of fly ash from the HHP of Grozny and the development of ash binders and high-quality concretes based on them. For carrying out the experimental studies, a Portland cement produced by state unitary enterprise "Chechen Cement" CEM I $42.5 \mathrm{~N}$, was used as the main binder, the main properties of the cement studied are shown in Table 1, chemical analysis is shown in \% by mass: $\mathrm{SiO}_{2}=17.45$; $\mathrm{Al}_{2} \mathrm{O}_{3}=3.88 ; \mathrm{Fe}_{2} \mathrm{O}_{3}=3.72 ; \mathrm{MgO}=1.12 ; \mathrm{CaO}=71.56 ; \mathrm{SO}_{3}=$ $0.76 ; \mathrm{TiO}_{2}=0.33 ; \mathrm{K}_{2} \mathrm{O}=1.07 ; \mathrm{Na}_{2} \mathrm{O}=0.11$.

TABLE I. THE MAIN CEMENT PROPERTIES

\begin{tabular}{|c|c|c|c|c|c|c|c|}
\hline \multirow[b]{2}{*}{$\begin{array}{c}\text { Producing } \\
\text { plant and } \\
\text { quality class }\end{array}$} & \multirow[b]{2}{*}{$\begin{array}{c}\text { Specific } \\
\text { surface } \\
\text { area, } \\
\mathrm{m}^{2} / \mathrm{kg}\end{array}$} & \multirow[b]{2}{*}{$\begin{array}{c}\mathrm{NC}, \\
\%\end{array}$} & \multirow[b]{2}{*}{$\begin{array}{c}\text { Density, } \\
\mathrm{kg} / \mathrm{m}^{3}\end{array}$} & \multicolumn{2}{|c|}{$\begin{array}{l}\text { Setting time, } \\
\text { hour - min. }\end{array}$} & \multicolumn{2}{|c|}{$\begin{array}{c}\text { Activity, } \\
\text { MPa, 28days }\end{array}$} \\
\hline & & & & 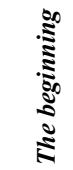 & 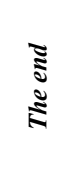 & 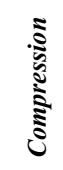 & $\frac{\sqrt[0]{5}}{3}$ \\
\hline $\begin{array}{c}\text { Chechen } \\
\text { Cement } \\
\text { CEM I 42.5 N }\end{array}$ & 330 & 25 & 3100 & $2-15$ & $3-40$ & 52.6 & 6.2 \\
\hline
\end{tabular}

In order to obtain ashy cement, ashy and slag wastes of heating power plants were investigated. It was found that they meet the requirements of State Industry Standard 25818-91 "Ashes of heating power plants for concrete. Technical conditions" and their main component are ashy microspheres.
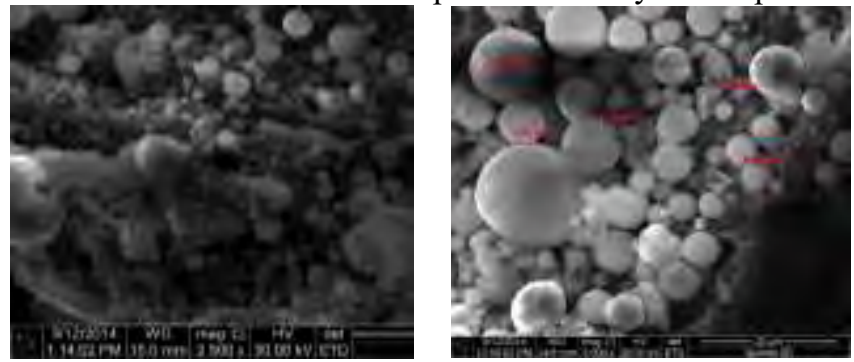

Fig. 2. Micrograph of ashy microspheres.

The study of ashy microspheres with the help of scanning electronic microscope (Figure 2) showed that they are presented by fine particles of gray color, spherical shape and brilliant smooth surface, the unevenness of various structures and sizes along with closed porous shells of individual microspheres were found. Chemical analysis of ashy microspheres is in \% in mass: $\mathrm{MgO}=1.49 ; \mathrm{Al}_{2} \mathrm{O}_{3}=23.89$; $\mathrm{SiO}_{2}=62.88 ; \mathrm{K}_{2} \mathrm{O}=0.48 ; \mathrm{CaO}=1.7 ; \mathrm{Fe}_{2} \mathrm{O}_{3}=7.95 ; \mathrm{TiO}_{2}=$ $0.11 ; \mathrm{SO}_{3}=0.06 ; \mathrm{ppp}=0.9$.

The analysis of the conducted studies showed that the basicity of ash $\mathrm{K}$ is an important indicator that determines the processes of structure formation and the formation of the strength of cement stone. It is the ratio of the sum of aluminum and iron oxides to the content of silicon oxide [12, 13]:

$$
K=\frac{\mathrm{Al}_{2} \mathrm{O}_{3}+\mathrm{Fe}_{2} \mathrm{O}_{3}}{\mathrm{SiO}_{2}}
$$

For the production of binders with improved properties, ashes with a $\mathrm{K}$ coefficient less than 0.8 are recommended; for the studied ash a coefficient is 0.5 . This indicator shows the presence of vitreous aluminosilicate phases activating the process of hydration of solid glass in alkaline medium $[1,2]$.

\section{RESULTS}

Further recipes of ash binders were developed, but before they were prepared, the ashes of heating power plants were subjected to mechanical activation for 40 minutes. The process of fine grinding in a mill contributes to the destruction of vitreous phase of a shell around ashy microspheres and reveals active crystallization centers on the surfaces capable of a pozzolanic reaction, and also provides a higher degree of homogenization of all the components of the resulting cement. The specific surface area was $S s p=920 \mathrm{~m}^{2} / \mathrm{kg}$. The degree of saturation of the binder with a fine ashy powder was determined experimentally, and the best ratio was $30 \%$ of ashy microspheres (AM) and $70 \%$ of Portland cement (PC). The results of the study of the properties of the resulting ashy cement are shown in Table 2.

TABLE II. THE MECHANICAL AND PHYSICAL PROPERTIES OF ASHY CONCRETE (30\% AM AND $70 \%$ PC)

\begin{tabular}{|c|c|c|}
\hline Characteristics & $\begin{array}{c}\text { Requirements (SIS } \\
\text { 31108-2003) }\end{array}$ & $\begin{array}{c}\text { Actual } \\
\text { characteristic }\end{array}$ \\
\hline \multicolumn{3}{|c|}{ Strength in 28 days, $\mathrm{MPa}$} \\
\hline - Bending & No limitations & 8.7 \\
\hline - Compression & Not less than 42,5 & 72.0 \\
\hline \multicolumn{3}{|c|}{ Strength in 3 days, $\mathrm{MPa}$} \\
\hline - Bending & No limitations & 4.55 \\
\hline - Compression & Not less than 20,0 & 21.0 \\
\hline Specific surface, $\mathrm{m}^{2} / \mathrm{kg}$ & No limitations & 520 \\
\hline Sulfur oxide content (VI) $\mathrm{SO}_{3}, \%$ & Not more than 4,0 & 3.5 \\
\hline Normal consistency of cement test, $\%$ & No limitations & 26.0 \\
\hline \multicolumn{3}{|c|}{ Setting time (h: $\min )$} \\
\hline - the beginning & not earlier than $60 \mathrm{~min}$ & $2: 50$ \\
\hline - the end & No limitations & $4: 10$ \\
\hline $\begin{array}{l}\text { Uniformity of volume change } \\
\text { (expansion), } \mathrm{mm}\end{array}$ & Not more than 10,0 & 1,5 \\
\hline $\begin{array}{l}\text { Specific effective activity of natural } \\
\text { radionuclides, Bk/kg }\end{array}$ & Not more than 370 & 73 \\
\hline
\end{tabular}

The activity of the resulting ashy binder was $72 \mathrm{MPa}$, the Figure 3 shows the kinetics of the strength of the developed cements. The studied properties of the resulting ashy binder confirmed the effectiveness of the developed cement, and at the next stage high-strength concrete was designed using it. 


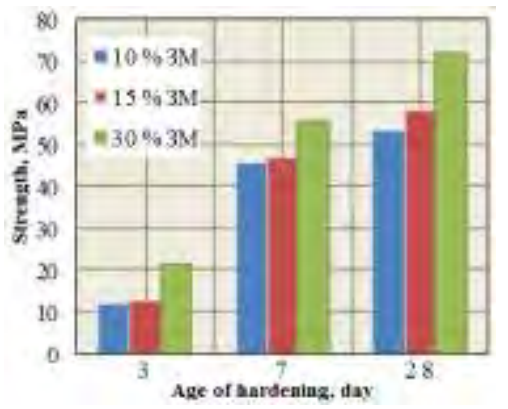

Fig. 3. The kinetic of the set of ashy binder strength.

Due to the lack of high-quality coarse sands in the region, fractionated fine aggregates were used, obtained by mixing fine sand of Chervlenskoye deposit $\mathrm{Mkr}=1.7$ and screening of rocks crushing of Argun open pit $\mathrm{Mkr}=3.2$ in the ratio of 1: 1 . (The ratio was determined experimentally).

According to approximate statistical data, up to 350 thousand $\mathrm{m}^{3}$ per year of waste in the form of dispersed stone dust, chips, stone crushing screenings are formed and accumulated at non-metallic plant materials in the region. The Figure 4 shows the surface relief and the morphology of these particles [1, 2, 14-16].

These products are distinguished by an acute-angular shape and a relief surface of particles, and the grain composition of stone crushing wastes is mainly represented by fractions $2.5-1.25 \mathrm{~mm}$ and particles less than $0.16 \mathrm{~mm}$, which provides better adhesion in the zone of contact of artificial sand with the cement component and positively affects the strength of concrete.

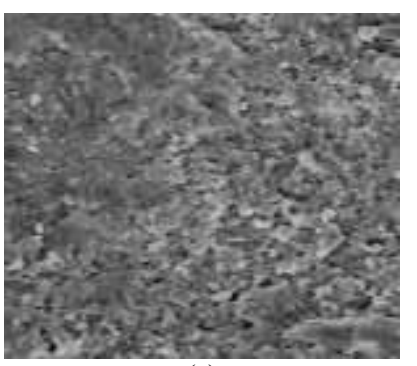

(a)
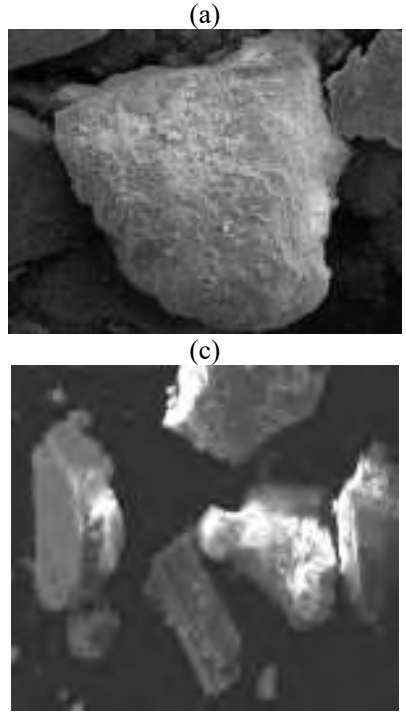

(e)

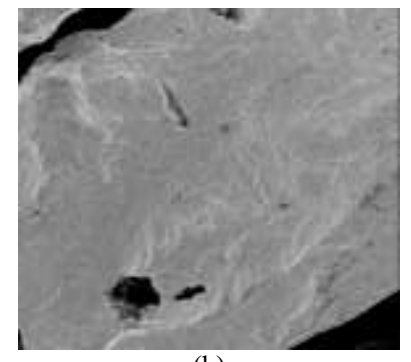

(b)

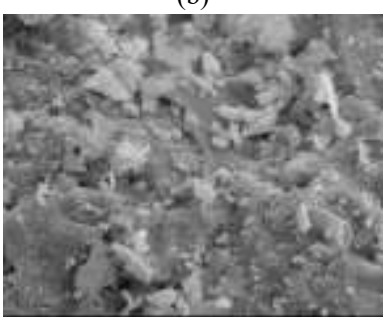

(d)

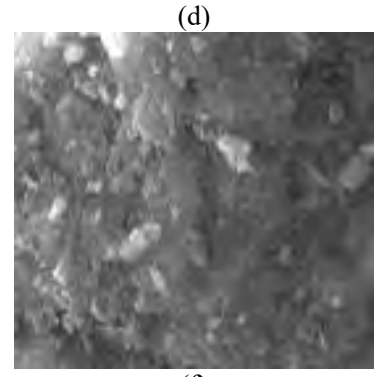

(f)
Fig. 4. The shape and morphology of particles surface of waste stone crushing in Argun deposit: a) the particles surface of waste stone crushing in a washed state; b) the earthy structure of individual grains; c) a grain of particles of waste stone crushing; g) the surface of grain wastes stone destruction; e) grains of cube-shaped and flaky shape; e) dense coating on the surface of quartz from a clay substance.

Taking into account the economic side, it is necessary to note that the cost of aggregate from crushing waste is significantly lower (up to 6-10 times) than natural sands, and their use reduces the cost of $1 \mathrm{~m}^{3}$ of concrete by $10 \%$ [1,5-7]. The main properties of the fractionated aggregate are shown in Table 3; Figure 4 shows the sieving curve of the sands obtained.

TABLE III. THE MECHANICAL AND PHYSICAL PROPERTIES FRACTIONATED FINE AGGREGATES

\begin{tabular}{|c|c|c|c|c|c|c|c|}
\hline Sieve size, $\mathbf{m m}$ & 5 & 2.5 & 1.25 & 0.63 & 0.315 & 0.14 & bottom \\
\hline Partial residuals, $\%$ & 4.7 & 10.9 & 7.3 & 12.0 & 50.8 & 12.6 & \multirow{2}{*}{1.7} \\
\hline Complete residuals, $\%$ & 4.7 & 15.6 & 22.9 & 34.9 & 85.7 & 98.3 & \\
\hline Size modulus & \multicolumn{7}{|c|}{2.62} \\
\hline $\begin{array}{l}\text { The content of dust and } \\
\text { clay particles, } \%\end{array}$ & \multicolumn{7}{|c|}{2.4} \\
\hline Real density, $\mathrm{g} / \mathrm{sm}^{3}$ & \multicolumn{7}{|c|}{2.56} \\
\hline Bulk density, $\mathrm{g} / \mathrm{sm}^{3}$ & \multicolumn{7}{|c|}{1.528} \\
\hline Void ratio, $\%$ & \multicolumn{7}{|c|}{42.4} \\
\hline
\end{tabular}

To obtain high-strength concrete, cube-shaped stone of the Alagirskoye deposit from granite-diabase rocks of a fraction of 5-10 and 10-20 mm was used, the strength of crushed stone is M1200, it was purchased for tests from the Republic of North Ossetia-Alania. At the same time, the coarse aggregate consisted of a compound of fractions of 5-10 mm and 10-20 $\mathrm{mm}$ with a ratio of 70:30 \%. The main physical and mechanical properties of coarse aggregate are shown in Table 4.

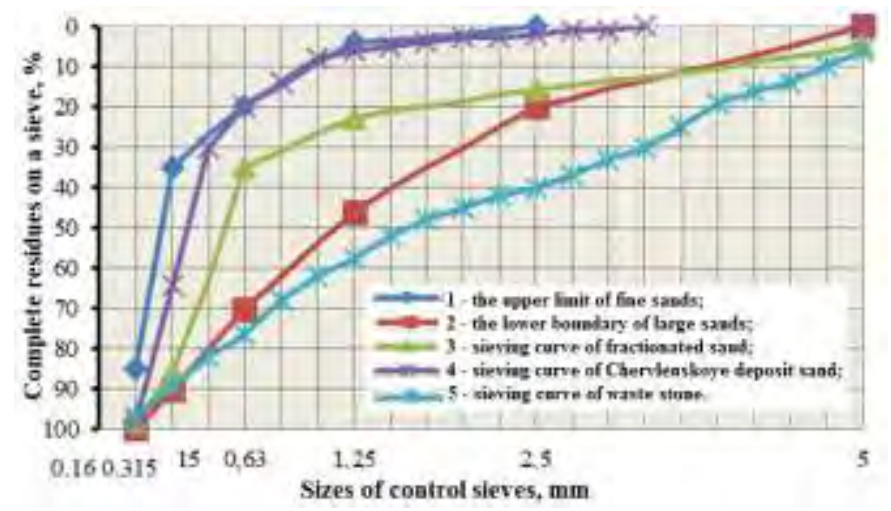

Fig. 5. The sieving curve of fine sands.

The last component used to obtain high performance concrete is a super plasticizer from Russian producers called Polyplast SP-1 based on polycarboxylate ethers, the additive was added with mixing water in various dosages, but the class of concrete mix on mobility remained constant $\mathrm{P} 4[4,6,13]$. 
TABLE IV. THE MAIN PROPERTIES OF COARSE AGGREGATE

\begin{tabular}{|l|l|c|c|c|c|c|}
\hline \multicolumn{1}{|c|}{ Parameter name } & \multicolumn{5}{c|}{ Parameter value } \\
\hline \begin{tabular}{l} 
Grain $\begin{array}{l}\text { composition } \\
\text { of broken } \\
\text { stone }\end{array}$ \\
\cline { 2 - 7 }
\end{tabular} & Size of sieves, mm & 12.5 & 10 & 7,5 & 5 & $<5$ \\
\cline { 2 - 7 } & Complete residues, \% residues, \% & 0.0 & 9.2 & 38.6 & 42.5 & 9.3 \\
\hline Strength test & \multicolumn{5}{|c|}{ M 1200} \\
\hline $\begin{array}{l}\text { The content of dust and clay particles, } \\
\%\end{array}$ & \multicolumn{5}{|c|}{2700} \\
\hline Real grain density, g/sm ${ }^{3}$ & 1450 \\
\hline Bulk grain density, g/sm ${ }^{3}$ & \multicolumn{5}{|c|}{85.2} \\
\hline The content of broken grain, \% & \multicolumn{5}{|c|}{12.2} \\
\hline $\begin{array}{l}\text { Determination of the content of grains } \\
\text { of lamellar (flaky) and needle-shaped } \\
\text { forms, \% }\end{array}$ & \multicolumn{5}{|c|}{44.9} \\
\hline Void ratio of stone, \% & \multicolumn{5}{|c|}{} \\
\hline
\end{tabular}

A concrete compound was obtained from the studied components with a draft of a cone from 16 to $20 \mathrm{~cm}$, which corresponds to the grade of mobility P4. Later 6 cubic specimen with a $10 \mathrm{~cm}$ edge were formed from the concrete compound of each composition/ They gained strength in the aging chamber with a relative power of $90 \%$ at a temperature of $20 \pm 20^{\circ} \mathrm{C}$ and they were subjected to a certain period of time. Table 5 shows the experimental compositions of the studied concretes and test results.

TABLE V. THE COMPOSITIONS AND PROPERTIES OF HIGH-STRENGTH CONCRETE

\begin{tabular}{|c|c|c|c|c|c|c|c|c|c|c|c|}
\hline \multirow[t]{3}{*}{ № } & \multicolumn{5}{|c|}{ Consumption, $\mathrm{kg}$ for $1 \mathrm{~m}^{3}$} & \multirow{3}{*}{$\frac{v}{k}$} & \multirow{3}{*}{ 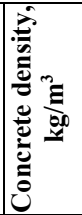 } & \multirow{3}{*}{ 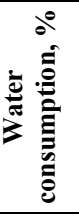 } & \multirow{3}{*}{ 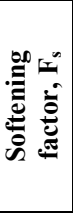 } & \multirow{2}{*}{\multicolumn{2}{|c|}{\begin{tabular}{|c|} 
Density for \\
compressio \\
$\mathbf{n}$ \\
$\mathrm{MPa}$ \\
\end{tabular}}} \\
\hline & \multirow{2}{*}{$\underset{\nabla}{\cup}$} & \multirow{2}{*}{ 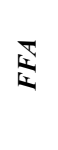 } & \multirow{2}{*}{ 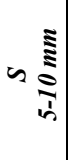 } & \multirow{2}{*}{$\omega \stackrel{\Xi}{\stackrel{\Sigma}{\Sigma}}$} & \multirow{2}{*}{ 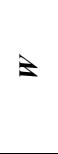 } & & & & & & \\
\hline & & & & & & & & & & 7 & 28 \\
\hline \multicolumn{12}{|c|}{ Polyplast additive consumption, 1,3\% } \\
\hline 1 & 460 & 870 & 617 & 265 & 170 & 0.37 & 2320 & 7.1 & 0.77 & 20.8 & 41.1 \\
\hline 2 & 480 & 870 & 600 & 252 & 178 & 0.37 & 2350 & 6.5 & 0.83 & 22.5 & 63.4 \\
\hline 3 & 500 & 840 & 610 & 262 & 185 & 0.37 & 2390 & 6.3 & 0.81 & 25.1 & 64.2 \\
\hline 4 & 520 & 860 & 600 & 270 & 192 & 0.37 & 2380 & 6.1 & 0.85 & 29.7 & 65.0 \\
\hline 5 & 520 & 810 & 600 & 300 & 192 & 0.37 & 2400 & 5.2 & 0.88 & 40.9 & 66.8 \\
\hline \multicolumn{12}{|c|}{ Polyplast additive consumption. $1.6 \%$} \\
\hline 6 & 460 & 870 & 617 & 265 & 161 & 0.35 & 2310 & 6.1 & 0.78 & 22.1 & 42.3 \\
\hline 7 & 480 & 870 & 600 & 252 & 168 & 0.35 & 2330 & 5.8 & 0.84 & 25.6 & 66.2 \\
\hline 8 & 500 & 840 & 610 & 262 & 175 & 0.35 & 2370 & 5.5 & 0.83 & 26.8 & 64.7 \\
\hline 9 & 520 & 860 & 600 & 270 & 182 & 0.35 & 2360 & 5.3 & 0.87 & 30.1 & 67.3 \\
\hline 10 & 520 & 810 & 600 & 300 & 182 & 0.35 & 2380 & 4.1 & 0.89 & 43.6 & 70.7 \\
\hline \multicolumn{12}{|c|}{ Companion specimen } \\
\hline 11 & 500 & 840 & 610 & 262 & 285 & 0.57 & 2410 & 9.5 & 0.63 & 16.3 & 40.2 \\
\hline
\end{tabular}

\section{IV.CONCLUSION}

It is necessary to note that the use of ash of Heating Power Plants in the amount of $30 \%$ of weight of Portland cement does not significantly affect the first period of hardening. but at 28 days and later terms. the strength evenly increases.

The use of ashy concrete and super plasticizer Polyplast favorably affects the processes of structure formation and the pore space of the cement stone. the consumption of an additive of $1.6 \%$ is the most optimal choice. The complex use of secondary resources allowed obtaining a water-resistant and high-strength composite. which has significantly better physical and mechanical properties in comparison with traditional concretes.

\section{References}

[1] S.A.Y. Murtazaev, M.Sh. Salamanova, "High-strength concretes with the use of fractionated aggregates from waste processing rocks," Journal of Sustainable Development of Mountain Territories, No 1 (23), pp.23$28,2015$.

[2] B. Hillemeier, G. Buchenau, R Herr, R. Huttl, Klubendorf St., Schubert K. "Spezialbetone. Betonkalender". Ernst \& Sohn, 2006.

[3] S.S. Kaprielov, "Modified high-strength concretes of classes B80 and B90 in monolithic structures," Building materials, No 3, pp. 9-13, 2008.

[4] R.G. Bisultanov, S.A. Murtazaev, M.Sh. Salamanova, "Cements of low water demand on the basis of an active mineral additive of various origin," Bulletin of Dagestan State Technical University. Technical science, No 1(40), pp. 98-107, 2016.

[5] S.A.Y. Murtazaev, M.Sh. Salamanova, R.G. Bisultanov, "High-quality modified concretes using a binder based on a reactive active mineral component," Building materials, No 8, pp. 74-80, 2016.

[6] V.S. Woodman. Anthropogenic metasamatosis in building materials science, International collection of scientific papers "Building materials - 4C: composition. structure. state. properties.” Novosibirsk. 2015.

[7] M.S. Ageeva, S.M. Shapovalov, A.N. Botsman, A.V. Ischenko, "On the issue of the use of industrial waste in the production of binders," Bulletin of Belgorod State Technological University, No. 9, pp. 58-62, 2016.

[8] N. Garg, "Pozzolanic reactivity of an interstratified illite/smectite (70/30) clay," Cement and Concrete Research, No 79, pp. 101-111, 2016.

[9] S. Zhang, D. Lu, Z. Xu, "Effect of dolomite powders on the hydration and strength properties of cement mortars," Proc. XIV International Congress on the Chemistry of cement. Beijing. China, 2015.

[10] W. Nocun-Wczelik, M. Szybilski, E. Zugaj, "Hydration of Portland cement with Dolomite," Proc. XIV International Congress on the Chemistry of cement. Beijing. China, 2015.

[11] A. Tironi, A.N. Scian, E.F. Irassar, "Hydration of ternary cements elaborated with limestone filler and calcined kaolinitic clay," Proc. XIV International Congress on the Chemistry of cement. Beijing. China, 2015.

[12] D.O. Bondarenko, N.I. Bondarenko, V.S. Bessmertnyi [etc.], "Plasmachemical modification of concrete." Advances in Engineering Research, vol. 157, pp. 105-110, 2018.

[13] V.V. Strokova, Y.V. Sokolova, A.M. Ayzenshtadt [etc.], "Energy characteristics of finely dispersed rock systems," IOP Conference Series: Materials Science and Engineering, vol. 365, 032036, 2018.

[14] V.V. Strokova, Y.V. Sokolova, A.M. Ayzenshtadt [etc.], "Surface tension determination in glyoxal-silica dispersed system," Journal of Physics: Conference Series, vol. 1038 (1), Iss. 1, 012141, 2018.

[15] Dosho Y., "Development of a Sustainable Concrete Waste Recycling System "Application of Recycled Aggregate Concrete Produced by Aggregate Replacing Method," Journal of Advanced Concrete Technology. Japan Concrete Institute. Scientific paper, vol. 5, No 1, pp. 27-42, 2005.

[16] K. Yanagibashi, T. Yonezawa, T. Iwashimizu [etc.], "A new recycling process for coarse aggregate to be used concrete structure." Environment-Conscious Materials and Systems for Sustainable Development, Proceedings of RILEM International Symposium. Tokyo. pp.137-143, 2004. 